\title{
Scapuladyskinesis: a vállelváltozások origója?
}

\author{
Kovács Dominik Norbert ${ }^{1}$ - Moldoványi Márton ${ }^{1}$ \\ Varga Veronika ${ }^{2}$ - Hock Márta dr. ${ }^{1}$ - Leidecker Eleonóra dr. ${ }^{1}$
}

${ }^{1}$ Pécsi Tudományegyetem, Egészségtudományi Kar, Fizioterápiás és Sporttudományi Intézet, Pécs ${ }^{2}$ Pécsi Tudományegyetem, Egészségtudományi Doktori Iskola, Pécs

\begin{abstract}
Bevezetés: A megváltozott statikus és/vagy dinamikus lapockapozíciót, azaz a scapuladyskinesist gyakran vonják párhuzamba a vállelváltozásokkal. Mindemellett a lapocka kinematikai eltérései nagy számban jelen lehetnek tünetmentes egyéneknél is, melegágyat biztosítva a későbbi vállelváltozások kialakulásának.

Célkitüzés: Munkánk fő célja az volt, hogy felhívja a figyelmet ezen problémakör fontosságára, valamint hogy megvizsgálja a scapuladyskinesis előfordulásának gyakoriságát és körülményeit az átlagpopulációban.

Módszer: Mintánk 70 fóből állt (átlagéletkor: 22,17 £ 1,77 év). 67\%-uk férfi, míg 33\%-uk nő volt. A scapuladyskinesis fennállását McClure-féle 'Scapular Dyskinesis Test'-tel vizsgáltuk. A résztvevők vállfájdalmának intenzitását vizuális analóg skála segítségével, habituális testtartásukat fotogrammetriás módszerrel, főbb lapockastabilizáló izmaik izomerejét pedig Kendall-féle manuális izomerőtesztekkel mértük fel. Mindemellett felvettük antropometriai adataikat, valamint megkérdeztük, hogy milyen gyakran végeznek sporttevékenységet.

Eredmények: A résztvevők 53\%-ánál találtunk valamilyen fokú scapuladyskinesist. A habituális testtartást vizsgáló fotogrammetriás felmérés eredményei és a scapuladyskinesist mérő McClure-féle teszt eredményei között szignifikáns összefüggést találtunk $(\mathrm{p}=0,01)$. A sportolási gyakoriság és a scapuladyskinesis előfordulása között jelentős összefüggést tapasztaltunk $(\mathrm{p}=0,01)$. A fájdalom erőssége és a scapuladyskinesis előfordulása között szignifikáns volt az összefüggés $(\mathrm{p}=0,03)$. A scapuladyskinesist mérő McClure-féle teszt és az azonos oldali felső végtagon izomerőcsökkenést mutató tesztek eredményei között szintén szignifikáns összefüggést tapasztaltunk $(\mathrm{p}=0,01)$.

Következtetés: Az elit sportolók mellett az átlagos populációban is jelentős mértékben jelen lehetnek a lapocka kinematikai eltérései. Mindez jelentős összefüggésben állhat az adott személy életmódjával és egészségmagatartásával, valamint kiemelt szerepet játszhat a krónikus vállfájdalom kialakulásában.
\end{abstract}

Orv Hetil. 2021; 162(15): 587-594.

Kulcsszavak: scapula, lapockacsont, váll, mozgás, biomechanikai jelenség

\section{Scapular dyskinesis: the origo of shoulder lesions?}

Introduction: The altered static and/or dynamic scapular position, i. e., scapular dyskinesis, is often paralleled with shoulder pathologies. However, shoulder kinematic abnormalities may also be present in large numbers in asymptomatic individuals.

Objective: The main goal of our work was to draw attention to the importance of scapular dyskinesis in shoulder pathologies.

Method: The final sample consisted of 70 people (average age: $22.17 \pm 1.77$ years), $67 \%$ of them was male and $33 \%$ female. The presence of scapular dyskinesis was assessed by McClure's Scapular Dyskinesis Test. Visual analog scale was used to examine the shoulder pain of the participants, photogrammetric method was used to document their habitual posture. Kendall's manual muscle testing methods were used to determine the muscle strength of the individual muscles of the shoulder girdle; we also recorded their anthropometric data and asked them about their sporting habits. Results: In 53\% of the participants, some degree of scapular dyskinesis was found. We observed significant correlation between the sporting habits and scapular dyskinesis $(\mathrm{p}=0.01)$. Significant correlation was observed between the posture and scapular dyskinesis $(\mathrm{p}=0.01)$. Between the strength of pain and the dyskinesis, we found a significant correlation $(p=0.03)$. There was a significant correlation between the results of the McClure's test and the tests showing muscle strength loss around the scapula $(\mathrm{p}=0.01)$.

Conclusion: In addition to elite athletes, scapular dyskinesis may also be significantly present in the average population and can play a key role in the development of shoulder pain.

Keywords: scapula, shoulder, movement, biomechanical phenomena

Kovács DN, Moldoványi M, Varga V, Hock M, Leidecker E. [Scapular dyskinesis: the origo of shoulder lesions?]. Orv Hetil. 2021; 162(15): 587-594.

(Beérkezett: 2020. augusztus 15.; elfogadva: 2020. október 13.) 
A lapockacsont kulcsfontosságú szerepet játszik a váll optimális funkciójában, megfelelő alapot biztosít a vállízület mozgásaihoz és stabilitásához. Fiziológiás elhelyezkedése facilitálja az optimális izomaktivitást, erőfejlesztést és erőátadást a kinetikus láncban, míg dinamikus mozgása maximalizálja a vállízület stabilitását és mozgástartományát [1]. A scapula saját mozgásai a felfelé/ lefelé rotáció, a kifelé/befelé rotáció, valamint az előre/ hátra billenés [2]. A claviculával összeköttetésben, ezekhez a mozgásokhoz társulnak még a vállöv protractiós/ retractiós és elevatiós/depressiós elmozdulásai. Mindezen mozgások összességéből áll a lapocka optimális, térbeli háromdimenziós mozgása, a scapulakynesis [2].

Korábbi vizsgálatok azt feltételezik, hogy a legtöbb vállelváltozás megjelenésében a lapocka körüli izomdiszfunkciónak komoly szerepe lehet $[3,4]$. A scapula stabilitásában és mozgásában elsődlegesen a musculus (m.) trapezius felső és alsó rostjai, valamint a m. serratus anterior és a mm. rhomboidei alkotta izompárok játszanak kulcsfontosságú szerepet. A megfelelő, fej feletti karfunkciókhoz elengedhetetlen a scapula hátrafelé billenése és kifelé rotációja $[5,6]$. Mindezek együttese teszi lehetôvé a vállizmok megfelelő aktivációját, amelyek aztán szinergizmusban dolgoznak a törzs- és csípőizmokkal. Ezen kinetikus lánc aktivációja facilitálja a periscapularis izmok maximális és optimális múködését [7]. A jelenlegi bizonyítékok azt mutatják, hogy a vállrendellenességekkel rendelkező egyéneknél fellelhetők a scapula kinematikai eltérései, ilyen a csökkent felfelé rotáció, a csökkent hátrafelé billenés és a kifelé rotáció [8-10].

A lapocka kórosan megváltozott helyzetét és/vagy mozgását a szakirodalomban scapuladyskinesisnek nevezik [11]. A lapocka nyugalmi helyzete kapcsán Kibler és mtsai 4 típust különböztettek meg, melyek közül egy a fiziológiás pozíciót, további három pedig dyskinesist jelöl. Az első típusnál az angulus inferior elbillen a hátsó mellkasfaltól ('type I'), a másodiknál a margo medialis prominens ('type II'), a harmadiknál, nyugalmi helyzetben a scapula felső éle billen el és anterior irányba mozdul el ('type III'), míg a negyedik típus a szimmetrikus, normális lapockapozíciót jelöli ('type IV') [12]. A scapula nyugalmi helyzeti eltérései mellé gyakran társulnak mozgás közbeni deviációk is, amelyek a vállízület kóros mozgásmintáit tartják fenn. Ez megnyilvánulhat a felkar mozgásai közben a scapula különböző részeinek prominenciájában, korai lapockaelevatióban, akadozó mozgásokban a kar emelése közben, illetve túlforgásban, rapid lefelé forgásban a kar leengedése során [11, 13].

Kibler és mtsai szerint a scapuladyskinesis multikauzális eredetű [14]. Okozhatják csontos tényezők, ilyenek például a gerinc kóros görbületei, a mellkas és a vállöv eltérései. Lehet a hátterében ízületi ok, például vállízületi kontraktúra, instabilitás, arthrosis vagy labrumpatológia. Neurológiai tényezők is állhatnak kialakulásának hátterében, ilyenek például a nyaki radiculopathia, a nervus (n.) thoracicus longus, a n. dorsalis scapulae és a XI. agyideg érintettsége. További kiváltó tényezők lehetnek a lágy részek elváltozásai, például az ízületi tok, szalag, fascia rugalmatlansága, a rotátorköpeny patológiái vagy a lapockastabilizáló izmok szakadása. Mindezek mellett, talán a leggyakrabban, a lapocka körüli, különböző neuromuscularis hiányosságok, mint az izomdiszfunkciók, az izomállóképesség-csökkenés és az izomaktivációs eltérések tartják fenn $[11,13,14]$.

A scapuladyskinesis sokféle eredetú lehet, egyfajta köztes tényezőként azonban sok vállelváltozás kialakulásában is szerepet játszhat. A scapuladyskinesis a vállelváltozások jelentős hányadában, 67-100\%-ban jelen lehet, fenntarthatja azok tüneteit [15]. A scapuladyskinesis lehetséges következményei közé sorolható a vállízületi impingement (ütközéses) szindróma, a mozgástartomány és -funkció csökkenése, a rotátorköpeny gyengülése, különböző elváltozásai, a glenohumeralis szalagok túlterhelődése, illetve a vállfájdalom [16-26].

A scapula kinematikájának eltéréseit eddig szinte csak elit sportolók, ezen belül is fej feletti aktivitást végző és dobósportolók körében vizsgálták. Egy korábbi metaanalízisben, amelyben 1257, fej feletti aktivitást végző sportolót vizsgáltak, 61\%-os scapuladyskinesis-előfordulási arányt jelentettek [27]; máshol ez az arány 419 sportoló esetében $38 \%$ volt [28].

Jelenleg kevés kutatás áll rendelkezésünkre az adott témában az átlagos, nem sportoló populáció tekintetében. Mivel a vállfájdalom megjelenése az átlagos életmódot folytatók körében is gyakori, vizsgálatunk célja volt, hogy felhívja a figyelmet a scapuladyskinesis gyakori előfordulására és velejáróira. Feltételeztük, hogy a habituális testtartás, a sportolási gyakoriság, a vállfájdalom, valamint a $\mathrm{m}$. serratus anterior, a $\mathrm{m}$. trapezius pars ascendens és a m. rhomboideus izomereje és a scapuladyskinesis előfordulása között összefüggések lehetnek. Figyelmünk középpontjában a különböző lágy szöveti és neuromuscularis faktorok által kiváltott, funkcionális okokra viszszavezethető scapuladyskinesis állt.

\section{Módszer}

Keresztmetszeti, nem randomizált vizsgálatot végeztünk kényelmi mintavétellel, egyetemisták körében. Beválasztási kritériumként a 18-26 év közötti életkort és az aktív hallgatói jogviszony meglétét adtuk meg. Kizárási kritériumként a vállöv, a vállízület, a gerinc korábbi traumatikus sérülését és strukturális elváltozásait, a nyaki radiculopathiát és porckorongsérvet, a n. thoracicus longus, a n. dorsalis scapulae és a XI. agyideg érintettségét, a korábbi mútétet és fizioterápiás kezelést a vállövi komplexumban, valamint a fej feletti sporttevékenységet jelöltük meg.

A vizsgálatot a Pécsi Tudományegyetem Laterum Kollégiumában végeztük 2019 novembere és 2020 márciusa között. Az alanyok önkéntes alapon, írásos hozzájárulás mellett vettek részt a kutatásban. A kollégium igazgatója írásban engedélyezte az infrastruktúra igénybevételét. 
A statisztikai elemzést Microsoft Excel 2019 programmal (Microsoft Corporation, Redmond, WA, Amerikai Egyesült Államok) végeztük, átlagértéket, tapasztalati szórást, korrelációs együtthatót számoltunk és t-próbákat, illetve khi-négyzet-próbát alkalmaztunk. A szignifikancia-szintet $\mathrm{p}<0,05$ értékben határoztuk meg.

\section{A scapuladyskinesis vizsgálata}

A scapuladyskinesis vizsgálatára a McClure és mtsai által kidolgozott, 'Scapular Dyskinesis Test'-et alkalmaztuk. Ennek megfelelően, a vizsgáló posterior aspektusból, 2-3 méter távolságból figyeli a lapockákat, miközben a vizsgálat alanya aktív vállízületi flexiót és abductiót végez, teljes mozgástartományban. A vizsgálat során mindegyik irányba 5 ismétlést szükséges végrehajtani úgy, hogy a felemelési és leengedési fázisa is, 3-3 másodpercig tartson [29]. Eközben a vizsgáló figyeli a lapockákat, egyenetlen, akadozó, kompenzáló mozgásokat és prominenciát keresve, kiemelt figyelmet fordítva a leengedés fázisára. A szerző ajánlásai szerint a vizsgálatot pontosabbá tehetjük, ha a végrehajtás során súlyokat alkalmazunk, az alanyok testsúlyának figyelembevételével. Esetünkben ez 68,1 kg testsúly alatt 1 kg volt karonként, e fölött pedig $2 \mathrm{~kg}$ karonként. A szerzői ajánlás szerint a lapockamozgások értékelése 3 kategória szerint történhet: normális dyskinesis, enyhe dyskinesis és egyértelmú scapuladyskinesis. A jobb és a bal lapocka mozgásait külön vizsgáltuk. Ha azonos oldalon az egyik irányba enyhe dyskinesist, a másikba pedig normálmozgásokat tapasztaltunk, akkor azt normálisnak, ha mindkét irányba enyhe dyskinesist, azt enyhének, ha pedig valamelyik irányba egyértelmü dyskinesist figyeltünk meg, azaz az 5 ismétlésből legalább 3-nál szembetűnó eltérés volt, azt egyértelmû dyskinesisnek vettük. Ugyanezt a metódust követtük a tesztek végeredményeinek összesítésekor, az adott személy dyskinesiskategóriába osztásakor. Az értékelést minden esetben ugyanaz, a témából alaposan felkészült szakember végezte (1. ábra).

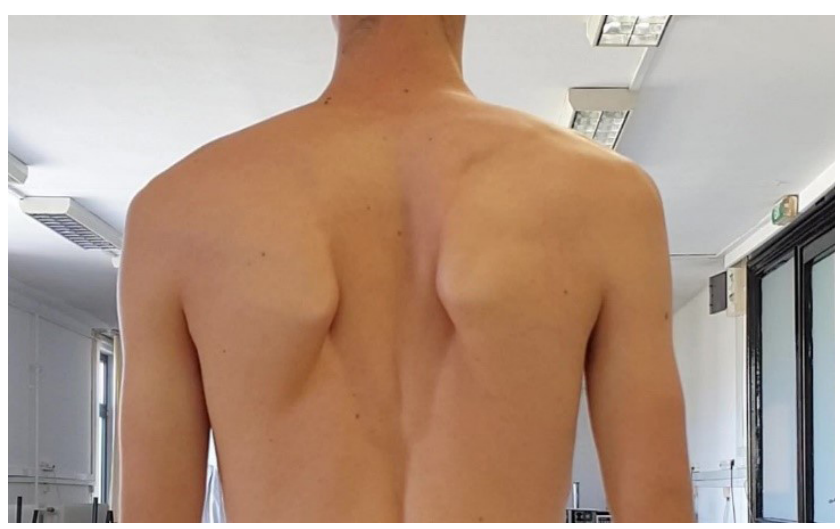

\begin{tabular}{l|l} 
1. ábra & A 'Scapular Dyskinesis Test'-ek végrehajtása közben tapasztalt
\end{tabular} egyértelmű scapuladyskinesis (saját fotó)

\section{A habituális testtartás vizsgálata}

A habituális testtartás vizsgálatára fotogrammetriás módszert alkalmaztunk. A vizsgált személyekről három fénykép készült, egy elölnézeti és két oldalnézeti. A fényképeket fal előtt készítettük, 2,4 méter távolságra az alanytól, úgy, hogy a kamera 1 méter távolságra volt a padlótól [30]. A fényképeket egy okostelefon (Samsung Galaxy S9+, 12,0 megapixel, F-szám: 2,4; Samsung Electronics Co., Ltd., Szuvon, Dél-Korea) kamerájával készítettük, az „ACPP Core2 Posture Measurement” (Jinyu Technology Co., Ltd., Zhejiang, Kína) applikációt használva, amely szimmetriarácsot és súlyvonalat vetített az alanyra. A vizsgálattal a szokványos testtartást mértük fel. A habituális testtartást meghatározó paramétereket egy megadott pontozási rendszer alapján értékeltük, szimmetriát-aszimmetriát és súlyvonalakat vizsgáltunk. A frontális síkban referenciapontunk volt a medence, a vállcsúcs, az orr, a köldök és a két lábfej. A sagittalis síkban viszonyítási pontunk volt a fül, a lumbalis I. és V. csigolya, valamint a malleolus lateralis. A szabad szemmel nem látható képleteket, kitapintásuk után, a résztvevők bőrfelületén jelöltük [31].

\section{Kérdöives vizsgálat}

Saját szerkesztésű kérdőívünkkel felvettük az alanyok antropometriai adatait, felmértük szubjektív fájdalomérzetüket a váll tájékán egy 0 -tól 10 -ig terjedő vizuális analóg skála segítségével [32]. Megkérdeztük, hogy milyen rendszerességgel végeznek legalább közepes fizikai megterheléssel járó, minimum 30 percig tartó sporttevékenységet. A későbbi értékelés megkönnyítésére itt az alábbi válaszlehetőségeket adtuk meg: „Soha”, „Ritkábban”, „Havonta 1-2 alkalommal”, „Hetente 1-2 alkalommal”, „Legalább heti 3 alkalommal”.

\section{Izomerö-vizsgálatok}

Vizsgálatunkban a lapocka pozicionálásában és mozgásainak irányításában kulcsfontosságú szerepet játszó izmok - a m. trapezius pars ascendens, a m. serratus anterior és a mm. rhomboidei - izomerejét vizsgáltuk. A vizsgálatokhoz a Kendall és mtsai által kidolgozott manuális izomerö-felmérő rendszert alkalmaztuk, tapasztalatainkat pedig az általánosan alkalmazott, 0-5-ös izomerőértékelő rendszer szerint osztályoztuk [33].

\section{Eredmények}

Kutatásunk résztvevőinek végleges száma 70 fó volt, a nemi eloszlást tekintve 67\%-uk férfi, 33\%-uk nő. Az alanyok átlagéletkora 22,17 $\pm 1,77$ év volt. $24 \%$-uk havi 1-2 alkalomnál ritkábban vagy soha nem végez legalább közepes fizikai megterheléssel járó, alkalmanként legalább 30 percig tartó fizikai aktivitást a szabadidejében, míg a heti legalább 3 alkalommal sportolók aránya 34\% volt. A habituális testtartás fotogrammetriás vizsgálatainak ki- 
1. táblázat | A 'Scapular Dyskinesis Test'-ek eredményei a vizsgált mintában

\begin{tabular}{lccc}
\hline & Férfi & Nő & Összesen \\
\hline $\mathrm{n}$ (fó) & 47 & 23 & 70 \\
\hline $\begin{array}{l}\text { Átlagéletkor (év) } \\
\text { Nincs scapuladyskine- } \\
\text { sis; n (\%) }\end{array}$ & $22,45 \pm 1,83$ & $21,61 \pm 1,53$ & $22,17 \pm 1,77$ \\
$\begin{array}{l}\text { Enyhe scapuladyskine- } \\
\text { sis; n (\%) }\end{array}$ & $11(23 \%)$ & $11(48 \%)$ & $33(47 \%)$ \\
$\begin{array}{l}\text { Egyértelmú scapula- } \\
\text { dyskinesis; n (\%) }\end{array}$ & $14(30 \%)$ & $6(26 \%)$ & $17(24 \%)$ \\
$\begin{array}{l}\text { Scapuladyskinesis } \\
\text { összesen; n (\%) }\end{array}$ & $25(53 \%)$ & $12(52 \%)$ & $37(53 \%)$ \\
\hline
\end{tabular}

értékelése szerint a mintában szereplők összesen 20\%ának fiziológiás a testtartása, a használt értékelési szempontok alapján. Az alanyok 69\%-ánál találtunk valamiféle eltérést a frontális síkban, 63\%-uknál pedig a sagittalis síkban. A vizsgált esetek 41\%-ánál állt fenn vállfájdalom, melynek átlagos, vizuális analóg skála szerinti erőssége $2,07 \pm 0,59$ volt.

A 'Scapular Dyskinesis Test' a résztvevők összesen 53\%-ánál bizonyult pozitívnak. A vizsgált alanyok 24\%ánál enyhe, 29\%-ánál pedig egyértelmű dyskinesist állapítottunk meg (1. táblázat). Mindezek mellett a vállmozgások közben tapasztalt scapuladyskinesissel rendelkező egyéneknél 68\%-ban volt jelen a lapocka nyugalmi helyzeti eltérése is.

\section{A babituális testtartás és a scapuladyskinesis összefüggései}

A habituális testtartás és a 'Scapular Dyskinesis Test'-ek eredményeinek vizsgálatai során a két változó átlagértékei között erôs, fordított irányú lineáris kapcsolatot jegyeztünk $(r=-0,96)$, azaz a habituális testtartás romlásával párhuzamosan jelentős mértékben emelkedett a scapuladyskinesis előfordulása és súlyossági foka. Az öszszefüggés szignifikáns volt $(\mathrm{p}=0,01)$. Mindemellett vizsgálati eredményeink kiértékelése során azt tapasztaltuk, hogy mind a sagittalis, mind a frontális síkú testtartásbeli eltérések és a scapuladyskinesis előfordulása között szignifikáns volt az összefüggés ( $\mathrm{p}_{\text {sag }}<0,01$; $\left.\mathrm{p}_{\text {front }}<0,01\right)$ (2. ábra).

\section{A sportolási gyakoriság és a scapuladyskinesis összefüggései}

A sportolási gyakoriságot felmérő kérdőívünk és az elvégzett 'Scapular Dyskinesis Test'-ek eredményeinek átlagértékei között erős, fordított irányú lineáris kapcsolat állt fenn $(\mathrm{r}=-0,98)$. Eredményeink azt mutatják, hogy a sportolási gyakoriság emelkedésével jelentős arányban csökkent a scapuladyskinesis előfordulási aránya és súlyossági foka. Az összefüggés szignifikanciájának megállapításakor jelentős összefüggést találtunk $(\mathrm{p}=0,01)$ (3. ábra).

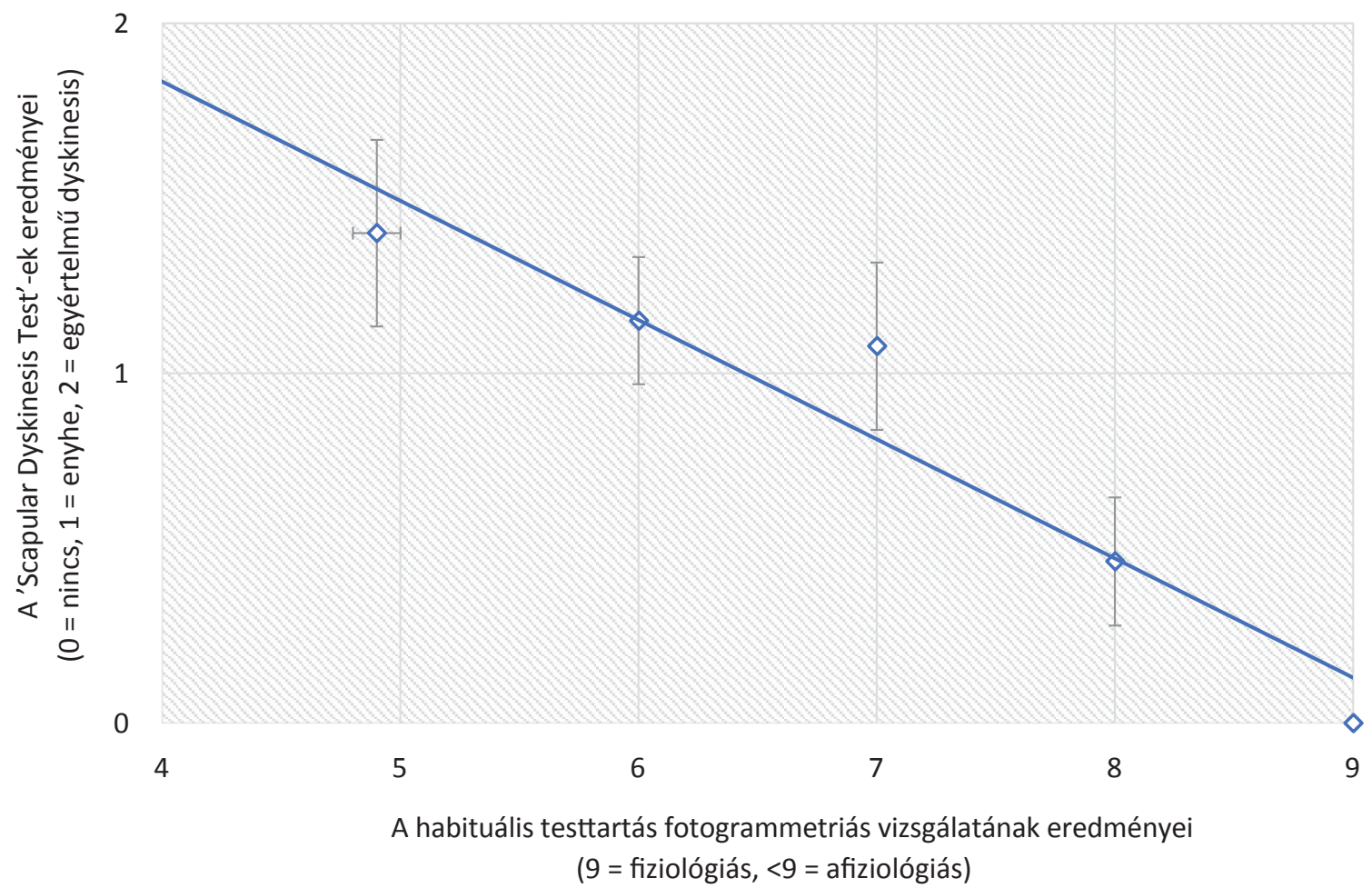

2. ábra $\quad$ A korreláció mértéke a habituális testtartás fotogrammetriás vizsgálata és a 'Scapular Dyskinesis Test'-ek eredményei között $(\mathrm{n}=70)$ 


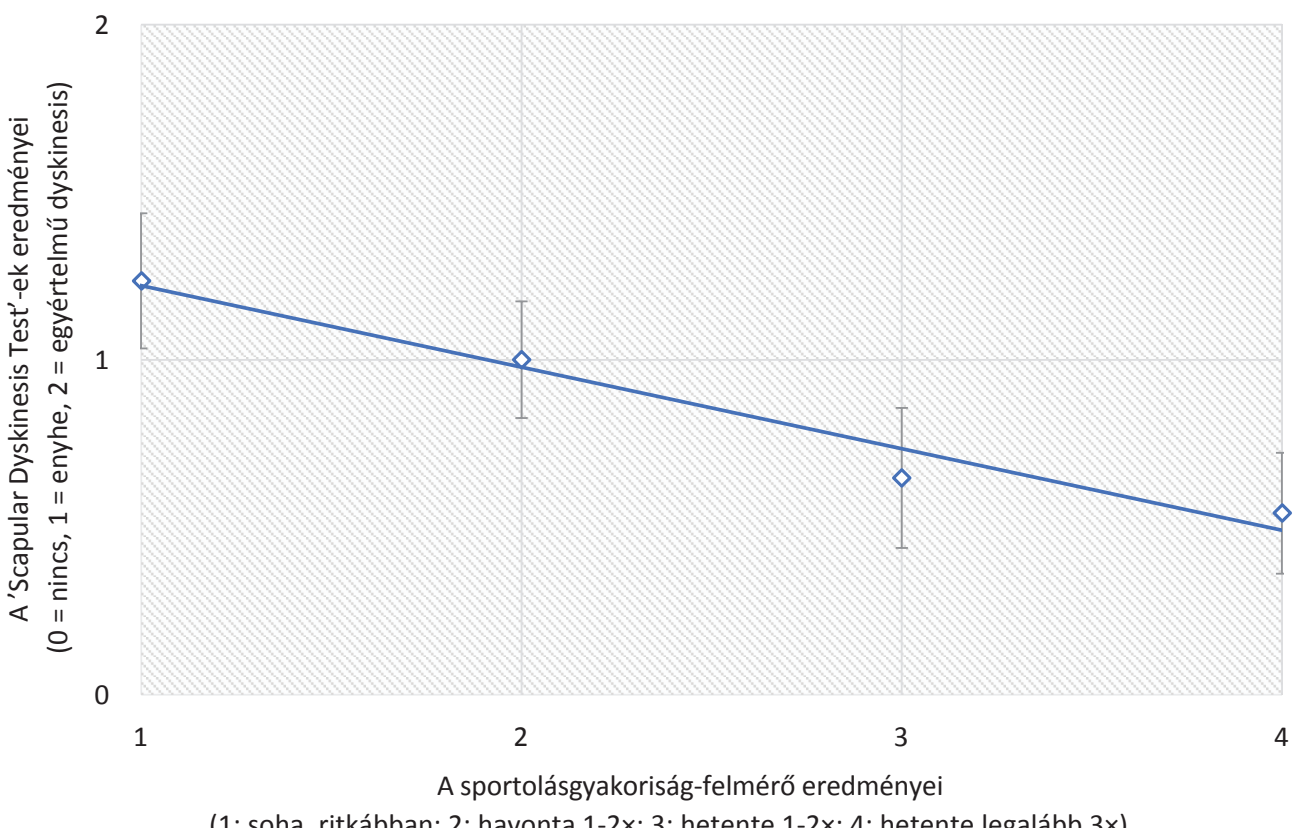

3. ábra A korreláció mértéke a sportolásgyakoriság-felmérő (4 kategória) és a 'Scapular Dyskinesis Test'-ek eredményei között
$(\mathrm{n}=70)$

2

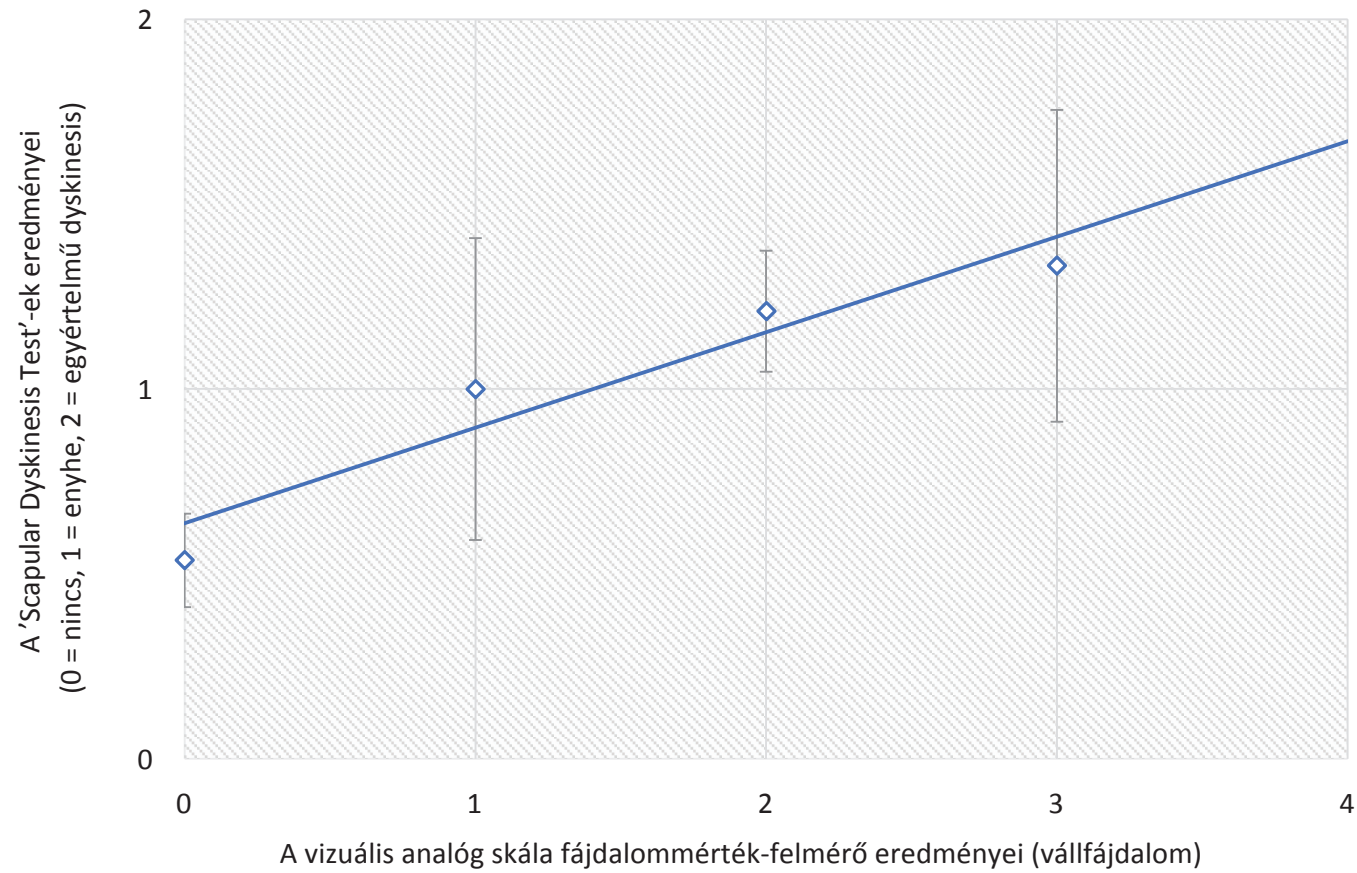

4. ábra

A korreláció mértéke a vizuális analóg skála fájdalommérték-felmérő és a 'Scapular Dyskinesis Test'-ek eredményei között $(\mathrm{n}=70)$

\section{A vállfájdalom és a scapuladyskinesis összefüggései}

Hipotézisünk teszteléséhez a vállfájdalmat mérő vizuális analóg skálák és a 'Scapular Dyskinesis Test'-ek eredményeit vetettük össze. A korrelációs együttható számítása során a két változó átlagértékei között erős lineáris kapcsolatot állapítottunk meg $(\mathrm{r}=-0,96)$. Az összefüggés szigni- fikánsnak mutatkozott ( $\mathrm{p}=0,03$ ), azaz a scapuladyskinesis megjelenésével párhuzamosan nőtt a vállfájdalom megjelenésének esélye és intenzitása. Fontos továbbá megjegyezni, hogy a scapuladyskinesissel rendelkezők 38\%-a nem jelentett fájdalmat, valamint azt is, hogy a teljes vizsgálati minta 9\%-ánál állt fenn negatív 'Scapular Dyskinesis Test' mellett vállájdalom, melynek átlagos, vizuális analóg skála szerinti erőssége $2,17 \pm 0,75$ volt (4. ábra). 


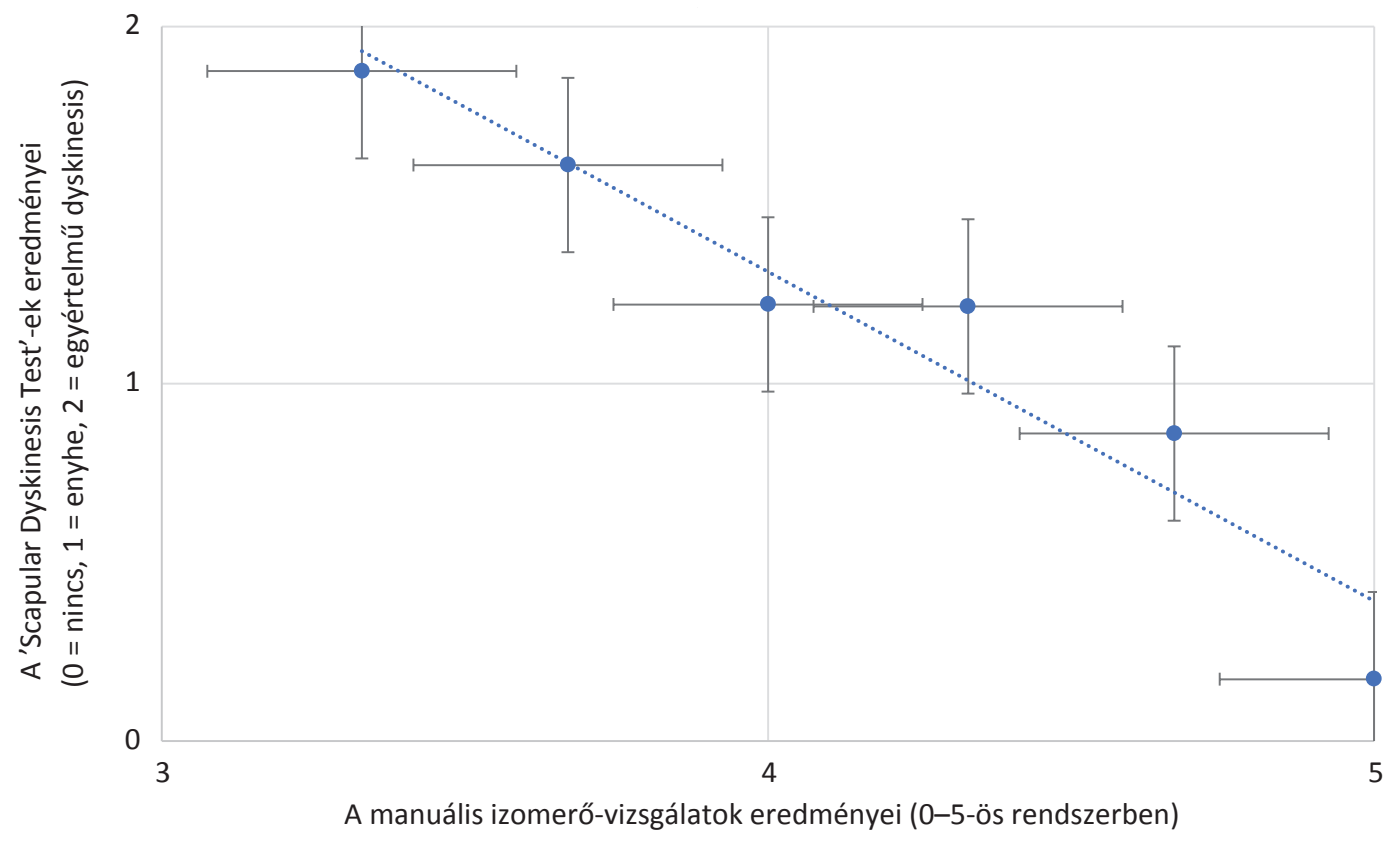

5. ábra $\quad$ A korreláció mértéke a vizsgált izmok összesített izomereje és a 'Scapular Dyskinesis Test'-ek eredményei között $(\mathrm{n}=70)$

\section{A vizsgált izmok izomereje és a scapuladyskinesis összefüggései}

A lapockastabilizáló izmok izomerő-vizsgálatainak és a 'Scapular Dyskinesis Test'-ek eredményeinek átlagértékei között erős, fordított irányú lineáris kapcsolatot találtunk $(\mathrm{r}=-0,94)$. A lapockastabilizáló izmok izomero"csökkenésével párhuzamosan jelentősen mértékben növekedett a scapuladyskinesis előfordulásának aránya $(\mathrm{p}=0,01)$. Továbbá az is jól megmutatkozott, hogy a scapuladyskinesissel rendelkezők körében jelentősen nagyobb arányban volt jelen a $\mathrm{m}$. serratus anterior és a m. trapezius pars ascendens izomerő-csökkenése, mint a rhomboideus izmoké $(\mathrm{p}<0,01)$. A pozitív esetek $76 \%$ ánál tapasztaltunk gyengülést a m. serratus anterior és a m. trapezius pars ascendens izmoknál, míg ez a szám a rhomboideus izmok esetében $41 \%$ volt (5. ábra).

\section{Megbeszélés}

Vizsgálatunk során jól megállapítható volt a scapuladyskinesis előfordulása és a habituális testtartás közötti kapcsolat. A testtartást, illetve a gerinc görbületeinek megváltozását más szerzők is feltételezik a lapocka kinematikai és pozícióbeli eltéréseinek hátterében, hiszen a scapulakinesishez elengedhetetlen egy stabil proximalis alap, amelyen létrejöhetnek a fiziológiás elmozdulások [11].

Vizsgálatunkból kizártuk azokat a személyeket, akik fej feletti sporttevékenységet folytattak, ezért eredményeinket a nem fej feletti aktivitást végző sportolókat vizsgáló kutatások eredményeivel hasonlítottuk össze. Saját vizsgálataink során $53 \%$-os scapuladyskinesis-elő- fordulási arányt találtunk az átlagos életmódot folytatóknál, míg ugyanez a megoszlás egy sportoló populációt vizsgáló kutatásban 33\% volt [27]. Mivel hipotézis-vizsgálataink során bizonyítást nyert, hogy a lapocka diszfunkciói összefüggést mutatnak a sportolási gyakorisággal, a kapott eredménybeli különbségek betudhatók annak, hogy saját vizsgálatunkban maximum hobbisportolók szerepeltek, a korábbi kutatásokban pedig hivatásos sportolókat vizsgáltak, akiknek feltételezhetóen magasabb a heti sportolási óraszámuk, ezáltal jobb fizikai kondíciónak és testtudatnak örvendhetnek, mint a saját mintánkban szereplő egyének.

Egy Hickey és mtsai által 2017-ben készített tanulmányban fej feletti és nem fej feletti aktivitást végző sportolókat vizsgáltak. A résztvevők 38\%-a rendelkezett scapuladyskinesissel. Ezen alanyok 35\%-ánál állt fenn vállfájdalom, míg a dyskinesissel nem rendelkezőknél ez a szám $25 \%$ volt [28]. Ugyanakkor saját kutatásunk során a dyskinesissel rendelkezők $62 \%$-a jelentett vállfájdalmat, míg az azzal nem rendelkezők 18\%-a. Eredményeink között a különbség jelentős, ami betudható a vizsgált populációk eltéréseinek, azonban a scapuladyskinesis és a vállfájdalom kapcsolata mindkét esetben jól megmutatkozik. Hickey és mtsai továbbá megállapították, hogy a scapuladyskinesis fennállása $43 \%$-kal emeli a vállfájdalmak kialakulásának veszélyét tünetmentes egyéneknél [28].

Több szerző is megjelöli az izmok diszfunkcióit mint potenciális kiváltó tényező́t a scapuladyskinesis hátterében $[11,13]$. Eredményeink tükrében elmondható, hogy a scapuladyskinesis és a fó lapockastabilizátor izmok izomerő-csökkenése között szignifikáns volt az öszszefüggés esetünkben is. 
Megállapításunkat egy korábbi kutatás is alátámasztja, amelynek során mérômúszerekkel állapították meg a scapularis izmok érintettségét, szignifikánsan csökkent aktivitását a scapuladyskinesissel rendelkezők körében [34].

\section{Következtetés}

Munkánk közlését fontosnak tartjuk, ugyanis hazai és nemzetközi viszonylatban is egyedülállónak gondoljuk. Míg eddig szinte kivétel nélkül elit sportolók körében vizsgálták a scapuladyskinesis előfordulását, saját vizsgálatunk egy átlagpopulációt mért fel, és kimutatta, hogy körükben is legalább olyan jelentős mértékben jelen lehetnek a lapocka kinematikai eltérései, mint a sportolók esetében, ezzel komoly esélyt adva a késóbbi vállelváltozások, vállfájdalom kialakulásának.

Kutatásunkban statisztikailag bizonyított az összefüggés a testtartás milyensége, az életmód és a scapuladyskinesis között. Mindezek tudatában, úgy gondoljuk, hogy a legnagyobb figyelmet a primer és szekunder prevencióra lehetne fordítani. Az iskolákban a testtartás és a lábtartás szűrése mellett vizsgálhatnánk a lapocka mozgásait is, mivel a váll egészségének megőrzésében is kiemelt szerepet játszik a megelőzés, a primer prevenció. Ennek vizsgálata nagy hatékonysággal megtörténhet vizuális obszervációval [11], az esetlegesen észlelt, neuromuscularis okokra visszavezethető scapuladyskinesis pedig a szekunder prevenció keretein belül jól kezelhető lenne gyógytornával. Mindezzel megelőzhető lenne az olyan, krónikus fájdalommal és életminőség-romlással járó vállelváltozások kialakulása felnőttkorban, amelyek manifesztálódásuk után hosszas konzervatív vagy akár mütéti kezelést igényelnek.

A szakirodalmi ajánlások egyetértenek abban, hogy a fizioterápiás kezelés első lépése a rövidült scapularis struktúrák nyújtása, flexibilitásuk helyreállítása, valamint a proximalis stabilitás megteremtése a törzs, a medence és a csípőízület területén, amely megalapozza a lapocka normálmozgásait. Majd a lapockacsontot és a felső végtagot is integráljuk a mozgásláncba, valamint megerősítjük a lapockastabilitást biztosító izmokat [11, 13].

A rendelkezésre álló adatok alapján elmondható, hogy nemcsak a sportolóknál, hanem az átlagos életmódot folytatóknál is oda kell figyelni a lapocka kinematikájára és annak megváltozására. Korábbi kutatások kimutatták, hogy a felnőttek egyharmadánál legalább egyszer előfordul vállfájdalom az életük során, valamint hogy a potenciálisan vállfájdalommal is járó elváltozások esetében 67-100\%-ban jelen lehetnek a scapula kinematikai eltérései, fenntarthatják azok tüneteit [15, 35-37]. Munkánk közlésével szeretnénk felhívni a figyelmet arra, hogy a scapuladyskinesis kiemelt szerepet játszhat a vállelváltozások kialakításában nemcsak a sportoló, hanem az átlagpopulációban is.
Anyagi támogatás: A szerzők anyagi támogatásban nem részesültek.

Szerzői munkamegosztás: K. D. N., V. V., L. E., M. M., H. M.: A vizsgálat tervezése és lefolytatása. K. D. N.: Statisztikai elemzések. K. D. N., M. M.: Irodalomkutatás. K. D. N., L. E., V. V.: A kézirat megszövegezése. A cikk végleges változatát valamennyi szerző elolvasta és jóváhagyta.

Érdekeltségek: A szerzőknek nincsenek érdekeltségeik.

\section{Irodalom}

[1] Kibler WB, Sciascia AD, Wilkes T. Disorders of the scapula: winging and snapping. In: Iannotti JP, Williams GR, Miniaci A, et al. (eds.) Disorders of the shoulder: diagnosis and management. Vol. 3, 3rd edn. Lippincott Williams and Wilkins, Philadelphia, PA, 2013.

[2] McClure PM, Michener LA, Sennett BJ, et al. Direct 3-dimensional measurement of scapular kinematics during dynamic movements in vivo. J Shoulder Elbow Surg. 2001; 10: 269-277.

[3] Cools AM, Witvrouw EE, Declercq GA, et al. Evaluation of isokinetic force production and associated muscle activity in the scapular rotators during a protraction-retraction movement in overhead athletes with impingement symptoms. Br J Sports Med. 2004; 38: 64-68.

[4] Cools AM, Witvrouw EE, Mahieu NN, et al. Isokinetic scapular muscle performance in overhead athletes with and without impingement symptoms. J Athl Train. 2005; 40: 104-110.

[5] Kibler WB, Sciascia A, Dome D. Evaluation of apparent and absolute supraspinatus strength in patients with shoulder injury using the scapular retraction test. Am J Sports Med. 2006; 34: 1643-1647.

[6] Smith J, Dietrich CT, Kotajarvi BR, et al. The effect of scapular protraction on isometric shoulder rotation strength in normal subjects. J Shoulder Elbow Surg. 2006; 15: 339-343.

[7] McMullen J, Uhl TL. A kinetic chain approach for shoulder rehabilitation. J Athl Train. 2000; 35: 329-337.

[8] Ludewig PM, Cook TM. Alterations in shoulder kinematics and associated muscle activity in people with symptoms of shoulder impingement. Phys Ther. 2000; 80: 276-291.

[9] McClure PW, Michener LA, Karduna AR. Shoulder function and 3-dimensional scapular kinematics in people with and without shoulder impingement syndrome. Phys Ther. 2006; 86: 10751090 .

[10] Timmons MK, Thigpen CA, Seitz AL, et al. Scapular kinematics and subacromial-impingement syndrome: a meta-analysis. J Sport Rehabil. 2012; 21: 354-370.

[11] Kibler WB, Ludewig PM, McClure PW, et al. Clinical implications of scapular dyskinesis in shoulder injury: the 2013 consensus statement from the 'Scapular Summit'. Br J Sports Med. 2013; 47: 877-885.

[12] Kibler WB, Uhl TL, Maddux JW, et al. Qualitative clinical evaluation of scapular dysfunction: a reliability study. J Shoulder Elbow Surg. 2002; 11: 550-556.

[13] Kibler WB, Sciascia A. Current concepts: scapular dyskinesis. Br J Sports Med. 2010; 44: 300-305.

[14] Kibler WB. The role of the scapula in athletic shoulder function. Am J Sports Med. 1998; 26: 325-337.

[15] Pluim BM. Scapular dyskinesis: practical applications. Br J Sports Med. 2013; 47: 875-876.

[16] Seitz AL, McClure P, Lynch SS, et al. Effects of scapular dyskinesis and scapular assistance test on subacromial space during static arm elevation. J Shoulder Elbow Surg. 2012; 21: 631-640. 
[17] Atalar H, Yilmaz C, Polat O, et al. Restricted scapular mobility during arm abduction: implications for impingement syndrome. Acta Orthop Belg. 2009; 75: 19-24.

[18] Silva RT, Hartmann LG, Laurino CF, et al. Clinical and ultrasonographic correlation between scapular dyskinesia and subacromial space measurement among junior elite tennis players. Br J Sports Med. 2010; 44: 407-410.

[19] Lukasiewicz AC, McClure P, Michener L, et al. Comparison of 3 -dimensional scapular position and orientation between subjects with and without shoulder impingement. J Orthop Sports Phys Ther. 1999; 29: 574-586.

[20] Tsai NT, McClure PW, Karduna AR. Effects of muscle fatigue on 3-dimensional scapular kinematics. Arch Phys Med Rehabil. 2003; 84: 1000-1005.

[21] Smith J, Kotajarvi BR, Padgett DJ, et al. Effect of scapular protraction and retraction on isometric shoulder elevation strength. Arch Phys Med Rehabil. 2002; 83: 367-370.

[22] Kibler WB, Sciascia AD, Dome DC. Evaluation of apparent and absolute supraspinatus strength in patients with shoulder injury using the scapular retraction test. Am J Sports Med. 2006; 34: 1643-1647.

[23] Tate AR, McClure PW, Kareha S, et al. Effect of the scapula reposition test on shoulder impingement symptoms and elevation strength in overhead athletes. J Orthop Sports Phys Ther. 2008; 38: 4-11.

[24] Weiser WM, Lee TQ, McMaster WC, et al. Effects of simulated scapular protraction on anterior glenohumeral stability. Am J Sports Med. 1999; 27: 801-805.

[25] Sütő G. Non-steroidal anti-inflammatory drugs for relieving pain in musculoskeletal disorders. [Nemszteroid gyulladáscsökkentő szerek a mozgásszervi fájdalom csillapításában.] Orv Hetil. 2019; 160: 855-860. [Hungarian]

[26] Sallai I, Weidl M, Szatmári A, et al. The change of fatty degeneration in the rotator cuff muscles after repair in patients over 65 . [Rotátorköpeny-szakadás után kialakult zsíros degeneráció változása az ín rekonstrukcióját követően, 65 éves kor után.] Orv Hetil. 2019; 160: 533-539. [Hungarian]

[27] Burn MB, McCulloch PC, Lintner DM, et al. Prevalence of scapular dyskinesis in overhead and nonoverhead athletes: a systematic review. Orthop J Sports Med. 2016; 4: 2325967115627608.
[28] Hickey D, Solvig V, Cavalheri V, et al. Scapular dyskinesis in creases the risk of future shoulder pain by $43 \%$ in asymptomatic athletes: a systematic review and meta-analysis. Br J Sports Med. 2018; 52: 102-110. [Epub 2017 Jul 22]

[29] McClure PW, Tate AR, Kareha S, et al. A clinical method for identifying scapular dyskinesis: part 1: reliability. J Athl Train. 2009; 44: 160-164.

[30] Iunes DH, Bevilaqua-Grossi D, Oliveira AS, et al. Comparative analysis between visual and computerized photogrammetry postural assesment. Rev Bras Fisioter. 2009; 13: 308-315.

[31] Kovácsné Bobály V, Szzilágyi B, Makai A, et al. Improvement of lumbar motor control and trunkmuscle conditions with a novel low back pain prevention exercise program. [Új low back pain prevenciós mozgásprogram, amely javítja a törzsizmok állapotát és a lumbalis motoros kontrollt.] Orv Hetil. 2017; 158: 58-66. [Hungarian]

[32] Járomi M, Betlehem J. Protecting the physical health of healthcare workers... $[\mathrm{Az}$ egészségügyi dolgozók fizikai egészségéért...] Nóvér 2005; 18(2): 21-23. [Hungarian]

[33] Kendall FP, McCreary EK, Provance PG, et al. Muscles: testing and function with posture and pain. Lippincott Williams \& Wilkins, Baltimore, MD, 2005.

[34] Huang TS, Ou HL, Huang CY, et al. Specific kinematics and associated muscle activation in individuals with scapular dyskinesis. J Shoulder Elbow Surg. 2015; 24: 1227-1234.

[35] Chard MD, Hazleman R, Hazleman BL, et al. Shoulder disorders in the elderly: a community survey. Arthritis Rheum. 1991; 34: 766-769

[36] Walker-Bone K, Reading I, Coggon D, et al. The anatomical pattern and determinants of pain in the neck and upper limbs: an epidemiologic study. Pain 2004; 109: 45-51.

[37] van der Heijden GJ. Shoulder disorders: a state-of-the-art review. Baillieres Best Pract Res Clin Rheumatol. 1999; 13: 287-309.

(Kovács Dominik Norbert, Pécs, Jókai utca 42.4/16, 7623 e-mail: kovacs.dominik.norbert@gmail.com)

\section{„Facta concludentia." (Utaló tények. - A tények beszélnek.)}

A cikk a Creative Commons Attribution 4.0 International License (https://creativecommons.org/licenses/by/4.0/) feltételei szerint publikált Open Access közlemény, melynek szellemében a cikk bármilyen médiumban szabadon felhasználható, megosztható és újraközölhető, feltéve, hogy az eredeti szerző és a közlés helye, illetve a CC License linkje és az esetlegesen végrehajtott módositások feltüntetésre kerülnek. (SID_1) 